\title{
Oracle: objectivizing cyanobacteria-associated risks in recreational waters
}

\author{
E. Baurès ${ }^{1,2}$, F. Pitois ${ }^{3}$, A. V. Jung ${ }^{4} \&$ O. Thomas ${ }^{1,2}$ \\ ${ }^{1}$ EHESP Rennes, Sorbonne Paris Cité, Rennes, France \\ ${ }^{2}$ INSERM, UMR IRSET 1085, LERES, Rennes, France \\ ${ }^{3}$ LIMNOLOGIE SARL, Rennes, France \\ ${ }^{4}$ School of Environmental Engineering (EME), Bruz, France
}

\begin{abstract}
The Oracle project intends to ameliorate the management methods of cyanobacteria and associated toxins crisis in a changing climate context. Various recent studies emphasize that in a changing climate environment, higher summer water temperatures could lead to an increase of algal proliferations. This could in turn necessitate a reinforcement of the monitoring of toxic cyanobacteria in recreational waters. The aims of this project are a better understanding of potentially toxic cyanobacteria crisis occurrences in recreational waters, and the development of predictive monitoring routines.

Our study is based on public health survey data from 26 recreational lakes monitored every year since 2004 in Brittany (north-west France) in order to encompass spatial and interannual patterns of cyanobacteria development on a regional scale.
\end{abstract}

This project includes 4 steps: (i) characterizing the annual rhythm of cyanobacteria development, (ii) defining site-specific reference conditions (iii) developing or improving remote survey techniques, (iv) developing new cyanobacteria monitoring protocols based on site-specific crisis indicators.

Exploring the links between cyanobacteria cell densities, toxin occurrences and interannual meteorological factors on one hand and characterizing the climate change consequences on local meteorological conditions on another hand can give us insights on the potential evolution of cyanobacterial crisis in the future.

Keywords: cyanobacteria, microcystins, climate change, recreational water quality. 


\section{Introduction}

Since their introduction in the public health debate [1-3], cyanobacteria and their toxins have gradually become a major concern for public health authorities. Literature reviews focusing on toxin production have been regularly published in the last 10 years, so biosynthetic pathways and toxicological issues are relatively well known [4-7].

There is however no evidence of any direct relation between cyanobacterial biomass and toxin concentration, nor any consensus on toxins origin and ecological role in the cyanobacterial cell life cycle. This lack of knowledge of toxin causality and of understanding of toxins purpose prevents any attempt in the prediction of risk occurrence.

The relations between cyanobacterial biomass and trophic enrichment (eutrophication processes) are widely admitted, whereas the influence of meteorological parameters on in situ algal growth is rarely discussed. Some abiotic parameters have nevertheless been studied in vitro in terms of selection and growth rates of potentially toxic species [8-13] and through their influence on toxin biosynthesis [14-18].

Reports of in vitro influence of light and temperature on cyanobacterial growth and toxin production emphasize the possible consequences of climate change on public health concerns. Exploring the relations between in situ abiotic factors, climate change consequences, cyanobacteria distribution and public health parameters on a regional scale is the main objective of the ORACLE project. This project was initiated in 2012 and is based on an analysis of monitoring data collected by local health authorities since 2004 in Brittany (NW France). This analysis should enlighten some aspects of the interannual dynamics of cyanobacterial development in 26 lakes used as recreative waters, and is directed toward the development of indices predictive of cyanobacteriaassociated risk crisis.

\section{Methodology}

\subsection{Data sources}

Our study is based on public health survey data from 26 recreational lakes monitored every year since 2004 in Brittany in the north-western quarter of France.

Cyanobacteria data, i.e. cell densities, species composition and microcystin concentrations, were collected from the regional public health authorities (Agence Régionale de Santé de Bretagne).

All other parameters were gathered from dedicated institutional databanks for hydrology (Minister for the Environment: BDHydro) and climate (MétéoFrance: Climathèque).

Lake morphology, i.e. depth, lake and watershed area, volume... came from Agence de l'Eau Loire-Bretagne or directly from lake owners. 


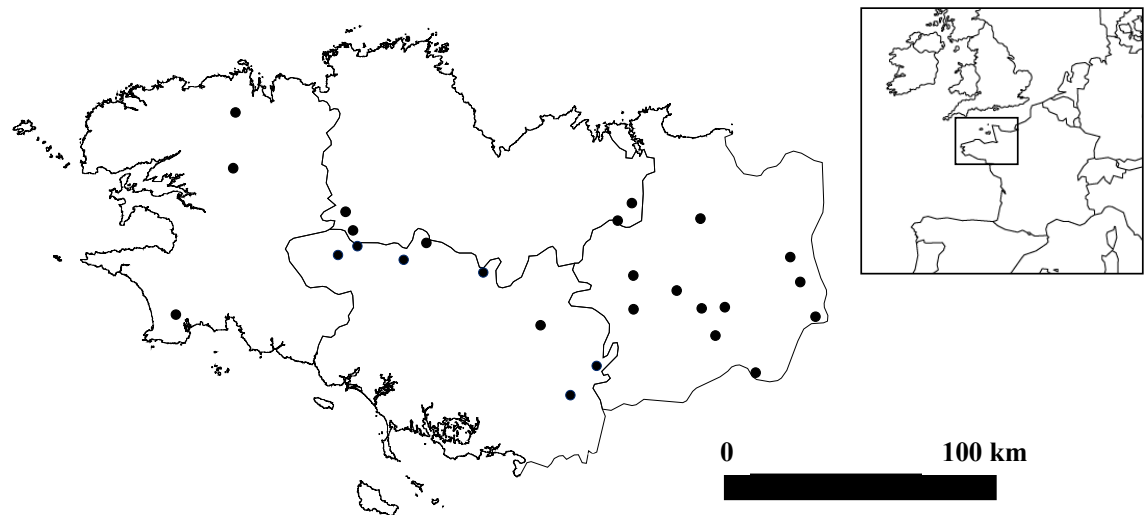

Figure 1: Brittany location and spatial distribution of the 26 investigated sites.

\subsection{Data limitations}

Several categories of limitation were identified with the monitoring data:

- Survey duration can vary every year on a local basis. Finding a common annual basis for data comparison in all sites reduced the time range to 16 weeks from early June to mid-September. This time range couldn't include all the initial cyanobacteria appearance phases (from March to May), nor their decay phase (from October to November): our data thus only cover $50 \%$ of the common time range where cyanobacteria can be observed in Brittany.

- Survey continuity: interannual exploitation of recreative waters cannot be assured, especially in case of low water quality. Only 26 sites out of a total of 40 could be considered as continuously monitored since 2004. Our data could then only account for $58 \%$ of the monitoring data potentially available under a continuous sampling program.

- Species composition lists are often incomplete, as sometimes all taxa considered as non-potentially toxic (chlorophyts, diatoms...) were left unidentified. Incomplete lists account for $23 \%$ of all the results available on the 26 selected sites.

- Hydrology: 30\% of all sites are subjected to hydrometric surveys, leaving 70\% of all discharges and residence times to be extrapolated from pluviometric data.

- Water quality monitoring for nutrients are only present in 2 lakes: no trophic status index could be integrated initially to the study.

- Toxin analysis: Microcystin (MCs) monitoring can rely on various methods (ELISA, HPLC, LC/MS) according to laboratories. None of these methods can give comparable results. The available MCs data were converted from quantitative results to positive detection frequencies, where a result higher than the highest quantification limit of all methods is considered a positive detection. 


\section{Results}

\subsection{Cyanobacteria and associated risk parameters}

The first phase of the study focused on generic risk parameters for all 26 sites: exposition intensity, i.e. cyanobacteria cell density; exposition duration, i.e. the number of weeks every year with cell density higher than WHO alert level 3 (100 $000 \mathrm{cell} / \mathrm{ml},[1])$; exposition recurrence, i.e. the number of years with cell density higher than WHO level 3 whatever the duration; and MCs annual detection frequencies.

This phase underlined:

- an interannual increase of the frequency of samples showing cell densities higher than WHO alert levels 2 and 3 (fig. 2a)

- a positive, annual relation between exposition duration and maximal cell densities (fig. 2b)

- a positive relation between interannual recurrence and annual exposition duration (fig. 2c)

- an inverse relation between MCs detection frequency and cyanobacteria cell density (fig. 2d)
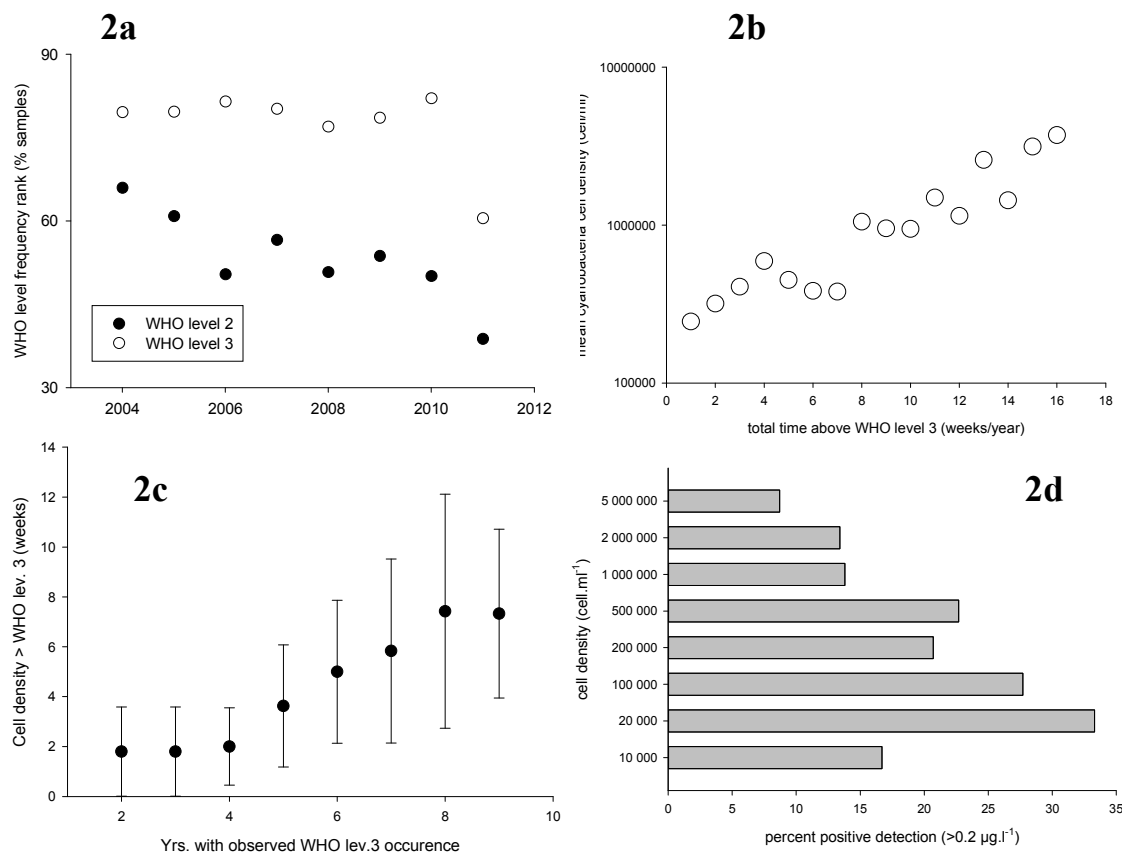

Figure 2: $\quad$ Cyanobacteria exposition parameters summarized, 2004-2011.

The abiotic factors identified as correlated with these health risk parameters are summarized in table 1. 
Table 1: Abiotic factors correlated with cyanobacterial risk parameters where $+/$ - are the Pearson correlation signs for $\mathrm{p}<0.05$.

\begin{tabular}{|l|c|c|c|c|}
\hline & Cell density & $\begin{array}{c}\text { Duration > } \\
\text { WHO lev. 3 }\end{array}$ & $\begin{array}{c}\text { Interannual } \\
\text { Recurrence }\end{array}$ & $\begin{array}{c}\text { MCs } \\
\text { detection } \\
\text { frequency }\end{array}$ \\
\hline Morphology & - & - & & \\
\hline Depth & & - & - & \\
\hline Surface & & & - & \\
\hline Watershed drainage index & & & & \\
\hline Meteorology & & & & + \\
\hline Summer temperature & & & & + \\
\hline Winter temperature & & - & & - \\
\hline Summer sunshine & + & + & & \\
\hline Winter sunshine & & & & \\
\hline Summer pluviometry & - & & & \\
\hline Winter pluviometry & & & & \\
\hline Position & - & - & & \\
\hline Longitude vs N. & & & & \\
\hline Latitude vs W. & & & & \\
\hline
\end{tabular}

\subsection{Cyanobacteria species composition}

Cyanobacteria species composition was separated into 5 subgroups according to taxonomic and cell dimensions criteria, and following the strategists' definition by Reynolds [19, 20] of c-strategists (competitor species), r-strategists (ruderal species) and s-strategists (stress-resistant species):

- r-Nostocales (e.g. Anabaena sp., Aphanizomenon sp.)

- c-Chroococcales (e.g. Aphanothece sp., Aphanocapsa sp., Merismopedia sp, Snowella sp....)

- s-Chroococcales (Microcystis sp., Worochininia sp.)

- c-Oscillatoriales (e.g. Limnothrix sp., Pseudanabaena sp.,...)

- r-Oscillatoriales (Planktothrix sp.)

The species known for potential toxin production are then the r-Nostocales, sChroococcales and r-Oscillatoriales. Our data show however that cell densities of r-Nostocales and s-Chroococcales are positively correlated with MCs detection frequency $\left(\mathrm{r}^{2}=0.55\right.$ et $\left.0.61, \mathrm{p}<0.05\right)$, which is not the case for $\mathrm{r}$-Oscillatoriales $\left(\mathrm{r}^{2}=-0.74, \mathrm{p}<0.05\right)$.

We defined group dominance as the frequency of one strategist group accounting for at least $50 \%$ of a sample total cell density. Under this assumption, only meteorological factors could be identified as correlated with group dominance episodes (table 2). Surprisingly, some winter conditions appeared correlated with cyanobacterial development in the next summer. 
Table 2: $\quad$ Factors correlated with dominance episodes of cyanobacterial strategist groups (+/-: Pearson correlation signs for $\mathrm{p}<0.05)$.

\begin{tabular}{|l|c|c|c|c|c|}
\hline & r-Nostoc. & c-Chrooc. & s-Chrooc. & c-Oscil. & r-Oscil. \\
\hline Meteorology & & & & & \\
\hline Summer temperature & + & - & & + & \\
\hline Winter temperature & & & & & + \\
\hline Summer sunshine & + & & & & - \\
\hline Winter sunshine & - & + & & - & \\
\hline Summer rain & - & & & & + \\
\hline
\end{tabular}

Interestingly, the s-Chroococcales (Microcystis, Worochininia) showed no correlation with any abiotic parameter, i.e. neither meteorology nor morphology. This can indicate that the relevant factors (trophic status index, residence time) are still to be integrated in the study.

\subsection{Cyanobacteria at the regional scale}

A dominance episode frequency mapping showed distinct NW-SE separations between 3 strategist groups: c-Chroococcales are concentrated in the western part of Brittany, whereas r-Nostocales and r-Oscillatoriales are concentrated in the eastern part (fig. 3). Dominance frequencies for c-Oscillatoriales and s-Chroococcales did not show notable geographic distribution.

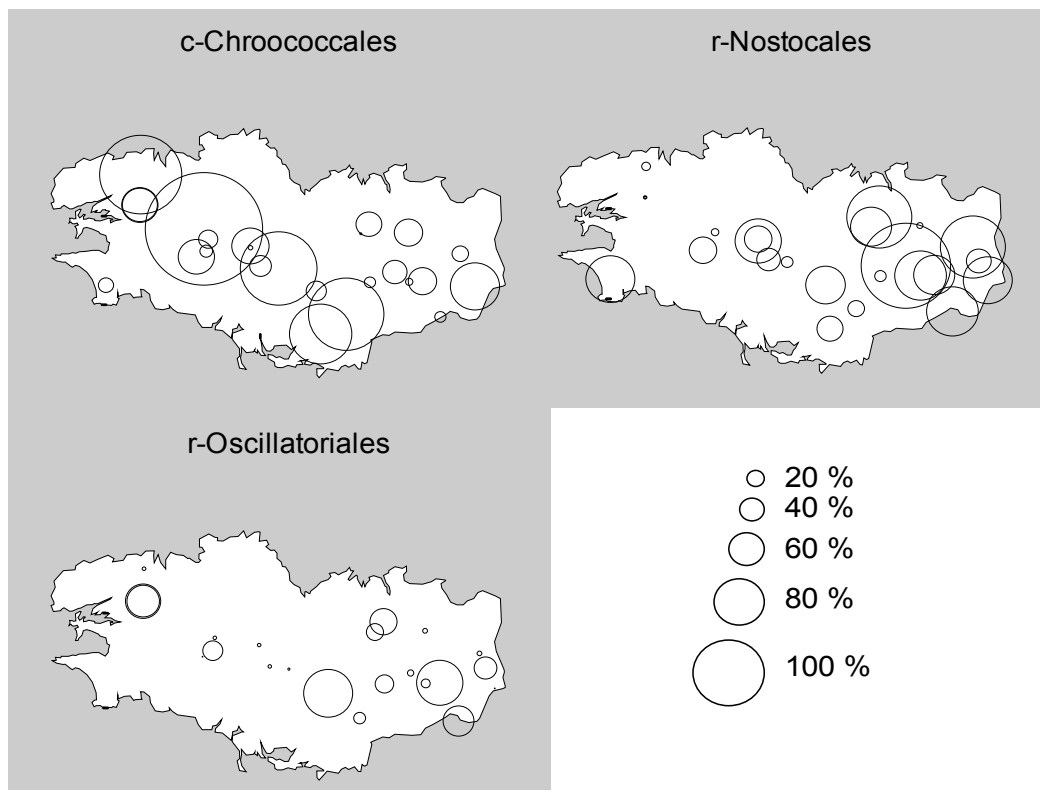

Figure 3: Spatial distribution of cyanobacterial group dominance frequency. 
This geographic distribution of c-Chroococcales, r-Nostocales and r-Oscillatoriales can be compared with their dependency to meteorological factors (table 2), and with regional climatic distribution of temperature, sunshine and rain during the growth period (i.e. May-October, fig. 4).
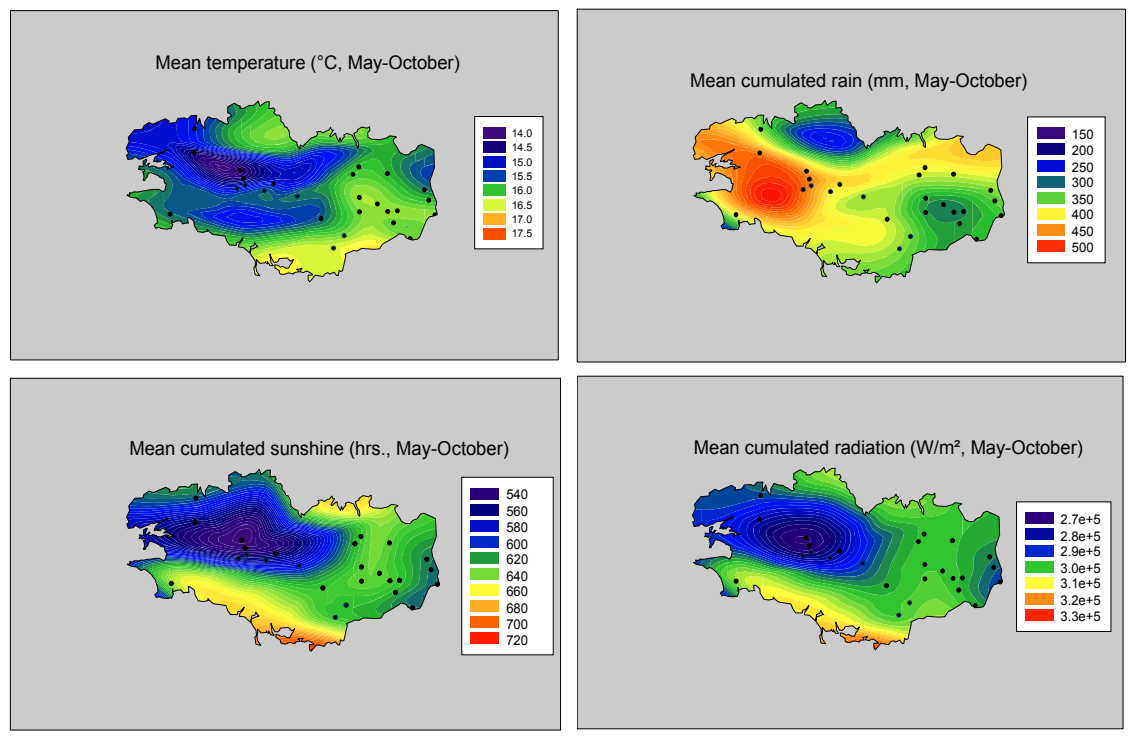

Figure 4: Climate parameters in Brittany inferred from 2001-2011 data.

Oceanic climate in Brittany shows a distinct separation along a NW to SE axis parallel to the sites distribution line, with increasing temperatures and sunshine and decreasing pluviometry in the SE direction. This can be compared with distribution data for r-Nostocales (temperature and sunshine: positive correlations) and s-Chroococcales (temperature: negative correlation), with cell densities and exposition duration (longitude: negative correlation), and with MCs detection frequency (temperature and sunshine: positive correlations).

Relating meteorological factors to cyanobacteria in a changing climate context is part of the ORACLE project. The temperature and pluviometry evolution for the May-October period were extrapolated from 1st order regression slopes and mapped (fig. 5). Temperatures show a strong tendency to increase in all Brittany, with a maximal increase rate on the northern coast. On the other hand, summer pluviometry tends to increase on the western and eastern sectors while decreasing in the center of Brittany.

Sunshine data are currently being completed at the regional scale, but the available data show a tendency to increase in the NW and SE quadrants, while decreasing in the NE and SW quadrants. This is of particular concern, as higher sunshine values and temperatures are positively correlated to r-Nostocales dominance phases and MCs detection frequencies. 


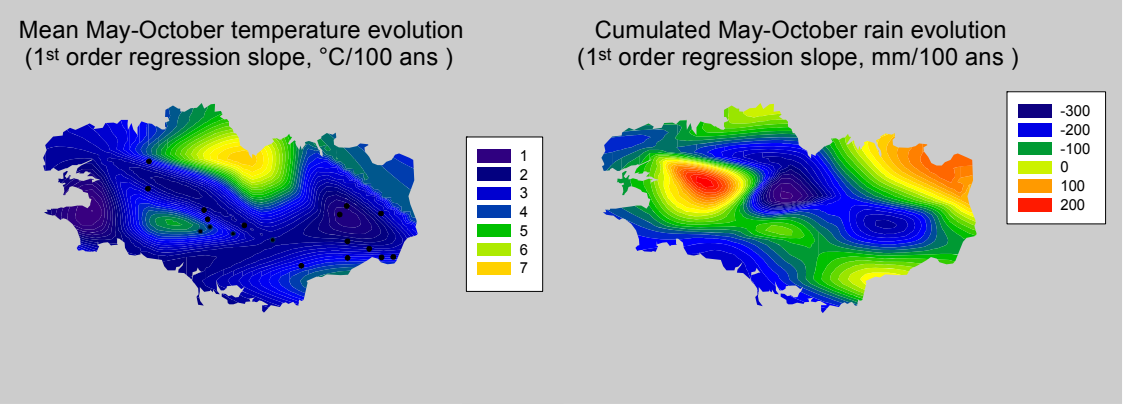

Figure 5: Evolution of temperature and pluviometry in Brittany extrapolated from monthly data 1981-2011.

\section{Conclusion}

At the end of its first year, the ORACLE project results are indicative of further potential development:

- site-specific morphological and climatic parameters could be integrated in a risk index indicative of each site ability to a recreative exploitation. This index could be used as a support for Bathing Water Directive 2006/7/CE [21], as this directive asks for the integration of cyanobacteria parameters without giving guidelines or risk parameter definitions.

- at the annual scale, parameters such as cell density, MCs detection frequency and exposure duration appear correlated with winter meteorology (e.g. pluviometry and sunshine hours). This could be developed as a predictive indicator of hazard situations before the beginning of recreative water use in the next summer.

- at the survey time scale, parameters such as temperature, sunshine hours and pluviometry appear to be indicators of crisis situation occurring in the next 20 to 30 days.

A closer use of meteorological surveys in the prediction of cyanobacteria and toxin occurrences appears to be an important perspective, potentially leading to alerting procedures directed specifically toward high cell densities and/or toxin occurrences.

As a wider development perspective, it can be noted that climate change consequences in Brittany are noticeable and show high geographic variability on a $300 \mathrm{~km}$ scale.

Several studies already described long-term modifications of cyanobacterial populations responses to climate change, in terms of proliferation frequencies (see for example [22-24]) or in terms of species composition [25-27], although in some cases no evolution can be highlighted [28].

Our results show a dependency of summer cyanobacteria populations not only on summer conditions, but also on winter meteorology. Moreover, long-term evolution of the summer and winter parameters can differ locally, or even show opposite slopes at small geographic scale. Integrating this small scale variability 
into a larger, regional scale model could enlighten the apparently opposite results of more site-specific studies.

\section{Acknowledgements}

The ORACLE project is funded by the French National Agency of Sanitary Security (ANSES) under the national program of Environment-Health-Work research (PNRSET 2012). The authors sincerely thank the French Agence Régionale de Santé (ARS) of Brittany and the French Agence de l'Eau LoireBretagne (AELB) for the data provided and are grateful to Caroline Farenc, student at the School of Environmental Engineering (EME), for the data exploitation.

\section{References}

[1] Chorus I., Bartram J., (1999), Toxic Cyanobacteria in Water: a Guide to Public Health Significance, Monitoring and Management. WHO, Chapman \& Hall, London, 416 pp

[2] Falconer I.R., (1989), Effects on human health of some toxic cyanobacteria (blue-green algae) in reservoirs, lakes, and rivers, Environmental Toxicology, 4, 175-184

[3] Falconer I.R., (1996), Potential impact on human health of toxic cyanobacteria. Phycologia, 35, 6-11

[4] Leflaive J., Ten-Hage L., (2007), Algal and Cyanobacterial secondary metabolites in freshwaters: a comparison of allelopathic compounds and toxins, Freshwater Biology, 52, 199-214

[5] Smith J.L., Boyer G.L., Zimba P.V., (2008), A review of Cyanobacterial odorous and bioactive metabolites: impacts and management alternatives in aquaculture, Aquaculture, 280, 5-20

[6] Aràoz R., Molgo J., Tandeau de Marsac N., (2010), Neurotoxic cyanobacterial toxins, Toxicon, 56, 813-828

[7] Pearson L., Mihali T., Moffitt M., Kellmann R., Neilan B., (2010), On the chemistry, toxicology and genetics of the cyanobacterial toxins, microcystin, nodularin, saxitoxin and cylindrospermopsin, Marine drugs, 8, $1650-1680$

[8] De Nobel W.T., Matthijs H.C.P., Von Elert E., Mur L.R., (1998), Comparison of the light-limited growth of the nitrogen-fixing cyanobacteria Anabaena and Aphanizomenon, New Phytologist, 138, 579-587

[9] Baker P.D., Bellifemine D., (2000), Environmental influences on akinete germination of Anabaena circinalis and implications for management of cyanobacterial blooms, Hydrobiologia, 427, 65-73

[10] Hadas O., Pinkas R., Malinsky-Rushansky N., Shalev-Alon G., Delphine E., Berner T., SukenikA., Kaplan A., (2002), Physiological variables determined under laboratory conditions may explain the bloom of Aphanizomenon ovalisporum in Lake Kinneret, European Journal of Phycology, 37, 259-267 
[11] McCausland M.A., Thompson P.A., Blackburn S.I., (2005), Ecophysiological influence of light and mixing on Anabaena circinalis (Nostocales, Cyanobacteria), European Journal of Phycology, 40, 9-20

[12] Yamamoto Y., Nakahara H., (2006), Importance of interspecific competition in the abundance of Aphanizomenon flos-aquae (Cyanophyceae), Limnology, 7, 163-170

[13] Imai H., Chang K-H., Kusaba M., Nakano S-I., (2009), Temperaturedependent dominance of Microcystis (Cyanophyceae) species: $M$. aeruginosa and $M$. weisenbergii, Journal of Plankton Research, 31, 171-178

[14] Rapala J., Sivonen K., (1998), Assessment of environmental conditions that favor hepatotoxic and neurotoxic Anabaena spp. strains cultured under light limitation at different temperatures, Microbial Ecology, 36, 181-192

[15] Wiedner C., Visser P.M., Fastner J., Metcalf J.S., Codd G.A., and Mur L.R., (2003), Effects of light on the microcystin content of Microcystis strains PCC 7806, Applied and Environmental Microbiology, 69, 14751481

[16] Tonk L., Visser P.M., Christiansen G., Dittmann E., Snelder E.O.F.M., Wiedner C., Mur L.R., Huisman J., (2005), The microcystine composition of the cyanobacterium Planktothrix agardhii changes toward a more toxic variant with increasing light intensity, Applied and Environmental Microbiology, 71(9), 5177-5181

[17] Briand E., Yéprémian C., Humbert J-F., Quiblier C., (2008), Competition between microcystin- and non-microcystin-producing Planktothrix agardhii (cyanobacteria) strains under different environmental conditions, Environmental Microbiology, 10(12), 3337-3348

[18] Preußel K., Wessel G., Fastner J., Chorus I., (2009), Response of cylindrospermopsin production and release in Aphanizomenon flos-aquae (Cyanobacteria) to varying light and temperature conditions, Harmful Algae, 8, 645-650

[19] Reynolds, 1998, Functional morphology and the adaptive strategies of freshwater phytoplankton, in C. D. Sandgren (ed.), Growth and reproductive strategies of freshwater phytoplankton. Cambridge University Press, New York: 388-433

[20] Reynolds, C. 2006. Ecology of Phytoplankton. Cambridge University Press. Cambridge, UK

[21] Official Journal of the European Union, 2006, Directive 2006/7/EC of 15 February 2006 concerning the management of bathing water quality and repealing Directive 76/160/EEC

[22] Carvalho L., Kirika A., (2003), Changes in shallow lake functioning: response to climate change and nutrient reduction, Hydrobiologia, 506-509, 789-796

[23] Malmaeus J.M., Blenckner T., Markensten H., Persson I., (2006), Lake phosphorus dynamics and climate warming: A mechanistic model approach, Ecological Modelling, 190, 1-14 
[24] Mooij W.M., Janse J.H., De Senerpont Domis L.N., Hülsmann S., Ibelings B.W., (2007), Predicting the effect of climate change on temperate shallow lakes with the ecosystem model PCLake, Hydrobiologia, 584, 443-454

[25] Nõges T., Nõges P., Laugaste R., (2003), Water level as the mediator between climate change and phytoplankton composition in a large shallow temperate lake, Hydrobiologia, 506-509, 257-263

[26] Wiedner C., Rücker J., Brüggemann R., Nixdorf B., (2007), Climate change affects timing and size of populations of an invasive cyanobacterium in temperate regions, Oecologia, 152(3), 473-484

[27] Liu X., Lu X., Chen Y., (2011), The effects of temperature and nutrient ratios on Microcystis blooms in Lake Taihu, China: An 11-year investigation, Harmful Algae, 10, 337-343

[28] Vasconcelos V., Morais J., Vale M., (2011), Microcystins and cyanobacteria trends in a 14 year monitoring of a temperate eutrophic reservoir (Aguieira, Portugal), J. Environ. Monit., 13, 668-672 